BALLOT BLOCKED 
STANFORD STUDIES IN LAW AND POLITICS Edited by Keith J. Bybee 


\title{
BALLOT BLOCKED
}

The Political Erosion of the Voting Rights Act

\author{
Jesse H. Rhodes
}

Stanford University Press

Stanford, California 
Stanford University Press

Stanford, California

C2017 by the Board of Trustees of the Leland Stanford Junior University.

All rights reserved.

No part of this book may be reproduced or transmitted in any form or by any means, electronic or mechanical, including photocopying and recording, or in any information storage or retrieval system without the prior written permission of Stanford University Press.

Printed in the United States of America on acid-free, archival-quality paper

Library of Congress Cataloging-in-Publication Data

Names: Rhodes, Jesse H., author.

Title: Ballot blocked : the political erosion of the Voting Rights Act / Jesse H. Rhodes. Description: Stanford, California : Stanford University Press, 2017. | Series: Stanford studies in law and politics | Includes bibliographical references and index.

Identifiers: LCCN 2017018234 (print) | LCCN 2017021934 (ebook) | ISBN 9781503603530 (e-book) | ISBN 9780804797597 (cloth : alk. paper) | ISBN 9781503603516 (pbk. : alk. paper)

Subjects: LCSH: Suffrage-United States-History-2oth century. | Suffrage-United States-History-21st century. | United States. Voting Rights Act of 1965. | Minorities-Suffrage-United States-History-2oth century. | MinoritiesSuffrage-United States-History-21st century.

Classification: LCC JK1846 (ebook) | LCC JK1846 .R46 2017 (print) | DDC 324.6/20973-dc23

LC record available at https://lccn.loc.gov/2017018234

Cover design: Matt Tanner

Typeset by Motto Publishing Services in 10/14 Minion 
To my wife, Megan, and my children, Jacob and Julia, who are always there to remind me of what is truly important. 
This page intentionally left blank 